\title{
New Wideband Passive and Active Wearable Energy Harvesting Systems for Wearable Sensors
}

\author{
Albert Sabban \\ Electrical Engineering Department, Ort Braude College, Karmiel, Israel \\ Email: sabban@netvision.net.il
}

How to cite this paper: Sabban, A. (2017) New Wideband Passive and Active Wearable Energy Harvesting Systems for Wearable Sensors. Journal of Sensor Technology, 7, 53-70.

https://doi.org/10.4236/jst.2017.74004

Received: October 31, 2017

Accepted: December 4, 2017

Published: December 7, 2017

Copyright $\odot 2017$ by author and Scientific Research Publishing Inc. This work is licensed under the Creative Commons Attribution International License (CC BY 4.0).

http://creativecommons.org/licenses/by/4.0/

\section{cc) (7) Open Access}

\begin{abstract}
Abstract: Demand for green energy is in continuous growth. Wide band efficient wearable systems and antennas are crucial for energy harvesting wearable systems for medical and sport wearable sensors. Small harvesting antennas suffer from low efficiency. The efficiency of energy harvesting wearable systems may be improved by using active wearable harvesting systems with low power consumption. Amplifiers may be connected to the wearable antenna feed line to increase the system dynamic range. Novel active wearable harvesting systems are presented in this paper. Notch and Slot antennas are low profile and low cost and may be employed in energy harvesting wearable systems. The wearable harvesting system components are assembled on the same PCB. The notch and slot antennas bandwidth is up to $100 \%$ for VSWR better than 3:1. The slot antenna gain is around $3 \mathrm{dBi}$ with efficiency higher than $90 \%$. The antennas electrical parameters were computed in vicinity of the human body. The active antenna gain is $24 \pm 2.5 \mathrm{~dB}$ for frequencies from 200 $\mathrm{MHz}$ to $900 \mathrm{MHz}$. The active antenna gain is $12.5 \pm 2.5 \mathrm{~dB}$ for frequencies from $1 \mathrm{GHz}$ to $3 \mathrm{GHz}$. The active slot antenna Noise Figure is $0.5 \pm 0.3 \mathrm{~dB}$ for frequencies from $200 \mathrm{MHz}$ to $3.3 \mathrm{GHz}$.
\end{abstract}

\section{Keywords}

Wearable Sensors, Energy Harvesting, Active Systems, Medical Applications, Sensor Chargers

\section{Introduction}

In last decade, ambient energy in the forms of light, vibration, heat and radio waves is employed to produce electricity from these different kinds of power 
sources [1]-[8]. Energy harvesting technology would decrease the need to replace batteries and power cables. It is important to receive the ambient RF power of multiple wireless systems to harvest as much energy as possible. In these cases, multiband and wideband antennas become crucial. Due to very low-received power densities, highly efficient radiators operating at specific frequency range and polarization states are employed. The preferred antenna radiation pattern should have a wide beam width.

Several printed antennas for harvesting energy applications were presented [1]-[8]. Small printed antennas are usually used in wearable communication and medical systems [9]-[35]. Electrical properties of human tissues have been investigated in [25] [26]. Human body effects on the electrical performance of wearable systems are investigated in this research. New wide band slot and notch antennas were developed for wearable harvesting energy applications. Printed slot and notch antennas are compact and has low production cost. Moreover, for active slot and notch antennas a compact low cost harvesting system may be developed by integrating the active components with the radiating elements on the same substrate. Wearable printed active antennas for harvesting energy applications are rarely presented in the literature. New wideband passive and active wearable antennas for harvesting energy applications are discussed in this paper. Amplifiers may be connected to the wearable antenna feed line to improve the system efficiency. Small light weight batteries supply the bias voltage to the active components of the energy harvesting devices. The proposed energy harvesting devices may be used in wearable wireless communication and medical systems. The active antenna bandwidth is around 200\% for VSWR better than 3:1. The active antenna gain is $22+2.5 \mathrm{~dB}$ for frequencies from $200 \mathrm{MHz}$ to 900 $\mathrm{MHz}$. The active antenna gain is $12.5+2.5 \mathrm{~dB}$ for frequencies from $1 \mathrm{GHz}$ to 3 $\mathrm{GHz}$.

\section{Active Energy Harvesting Concept}

Electromagnetic energy propagating in free space may be captured, stored and employed to charge batteries and for other commercial applications. RF energy is inversely proportional to distance and therefore drops as the distance from a source is increased. Harvested power from RF energy sources is lower than 0.1 $\mu \mathrm{W} / \mathrm{cm}^{2}$. Amplifiers may be connected to the wearable antenna feed line to improve the system efficiency. RF energy harvesting concept is shown in Figure 1. A DC unit manages and controls the DC power in the proposed system. There is an increase in the amount of radio wave in the air. The expected amount of radio Wave in the air in 2017 is 11 Exa-bytes per month as listed in Table 1. Today we can do more computations per KWh as listed in Table 2. Light is the best harvesting source. Light harvested power is around $100 \mathrm{~mW} / \mathrm{cm}^{2}$ with around $10 \%$ to $20 \%$ energy conversion efficiency. Thermal harvested power is around 60 $\mu \mathrm{W} / \mathrm{cm}^{2}$ with around $0.1 \%$ to $3 \%$ energy conversion efficiency. RF harvested power is around $1 \mu \mathrm{W} / \mathrm{cm}^{2}$ with around $50 \%$ to $60 \%$ energy conversion efficiency. The RF energy harvesting system consists of an antenna, a Rectifying circuit 


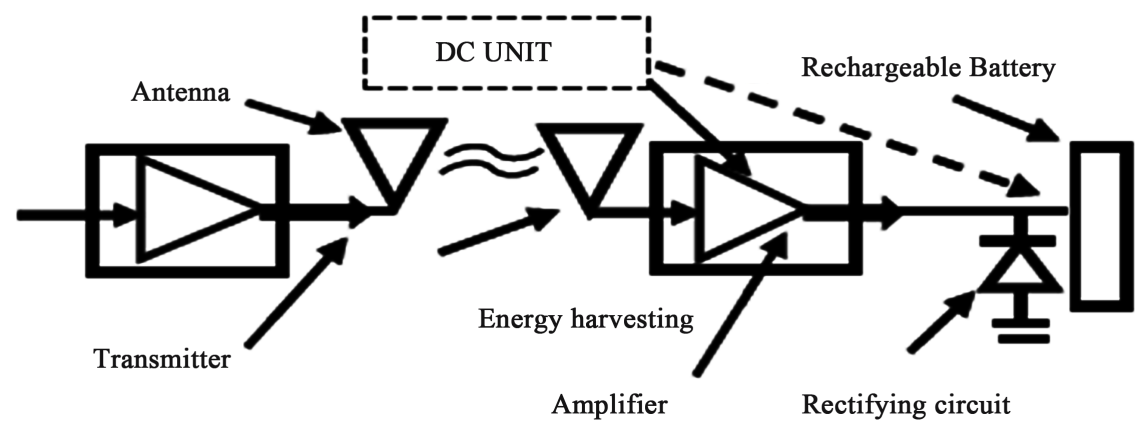

Figure 1. Active RF harvester block diagram.

Table 1. Amount of radio wave in the air.

\begin{tabular}{cc}
\hline Year & Amount of radio wave in the air Exa-bytes per month \\
\hline 2013 & 1.5 \\
2014 & 2.6 \\
2015 & 4.4 \\
2016 & 7 \\
\hline
\end{tabular}

Table 2. Computations per KWh.

\begin{tabular}{cc}
\hline Year & Computations per KWh $(1 \mathrm{E}+09)$ \\
\hline 1977 & 1 \\
1983 & 10 \\
1987 & 100 \\
1992 & 1000 \\
1997 & 10,000 \\
2003 & 100,000 \\
2008 & $1,000,000$ \\
\hline
\end{tabular}

and a rechargeable battery. We can calculate the energy harvesting link budget by using equations 1 to 4 .

$$
P_{r}=P_{t} G_{t} G_{r}\left(\frac{\lambda}{4 \pi R}\right)^{2}
$$

$L_{f r}$ represents propagation loss in free space. $L_{a t}$ attenuation Losses in atmosphere, should also be included in the transmission equation.

Where, $L_{f r}=\left(\frac{4 \pi R}{\lambda}\right)^{2}$. The received power may be given as: $P_{r}=\frac{P_{t} G_{t} G_{r}}{L_{f r}}$

$L_{p o l}$ are losses due to polarization mismatch. $L_{r}$ are losses associates with receiving antenna and with the receiver. Losses associates with the transmitting antenna as written as, $L_{t a}$

$$
P_{r}=\frac{P_{t} G_{t} G_{r}}{L_{p} L_{a} L_{t a} L_{r a} L_{p o l} L_{o} L_{r}}
$$




$$
P_{r}=\frac{E I R P \times G_{r}}{L_{p} L_{a} L_{t a} L_{r a} L_{p o l} L_{\text {other }} L_{r}}=\frac{P_{\text {out }} G_{t} G_{r}}{L_{t} L_{p} L_{a} L_{t a} L_{r a} L_{p o l} L_{\text {other }} L_{r}}
$$

where, $P_{t}=P_{\text {out }} / L_{t}, E I R P=P_{t} G_{t}$.

The transmitting antenna power is $P_{t} L_{t}$ presents the losses between power source and the antenna. The Effective Isotropic Radiated Power is EIRP.

$$
\begin{gathered}
G=10 \cdot \log \left(\frac{P_{\text {out }}}{P_{\text {in }}}\right) \mathrm{dB} \text { Gain in } \mathrm{dB} . \\
L=10 \log \left(\frac{P_{\text {in }}}{P_{\text {out }}}\right) \mathrm{dB} \text { Loss in } \mathrm{dB}
\end{gathered}
$$

$P_{r}$, received power, in $\mathrm{dBm}$ is given in Equation 4. $P_{r}$ is usually referred to as "Carrier Power". Mobile phone understandard 802.11 may transmit $30 \mathrm{dBm}$. Cards with 802.11 PCMCIA transmit around 10 to $20 \mathrm{dBm}$.

$$
P_{r}=E I R P-L_{t a}-L_{p}-L_{a}-L_{p o l}-L_{r a}-L_{\text {other }}+G_{r}-L_{r}
$$

\section{Wideband Notch Antenna, $2 \mathrm{GHz}$ to $7.8 \mathrm{GHz}$, for Energy Harvesting Applications}

A wideband notch antenna was printed on dielectric substrate with dielectric constant of 2.2 and $1.2 \mathrm{~mm}$ thick.

The antenna dimensions are $116.4 \times 71.4 \mathrm{~mm}$, as shown in Figure 2. The antenna bandwidth is around $100 \%$ for S11 lower than $-6.5 \mathrm{~dB}$, as presented in Figure 3. The antenna VSWR is better than 3:1 for frequencies from $2.1 \mathrm{GHz}$ to $7.8 \mathrm{GHz}$. The antenna gain is around $2.5 \mathrm{dBi}$ with $84^{\circ}$ beam width. Figure 4 present a typical radiation pattern of a notch antenna. These results agree with measured results. A rectifying circuit is connected to the antenna input. A rechargeable battery is connected to the output of the rectifying circuit.

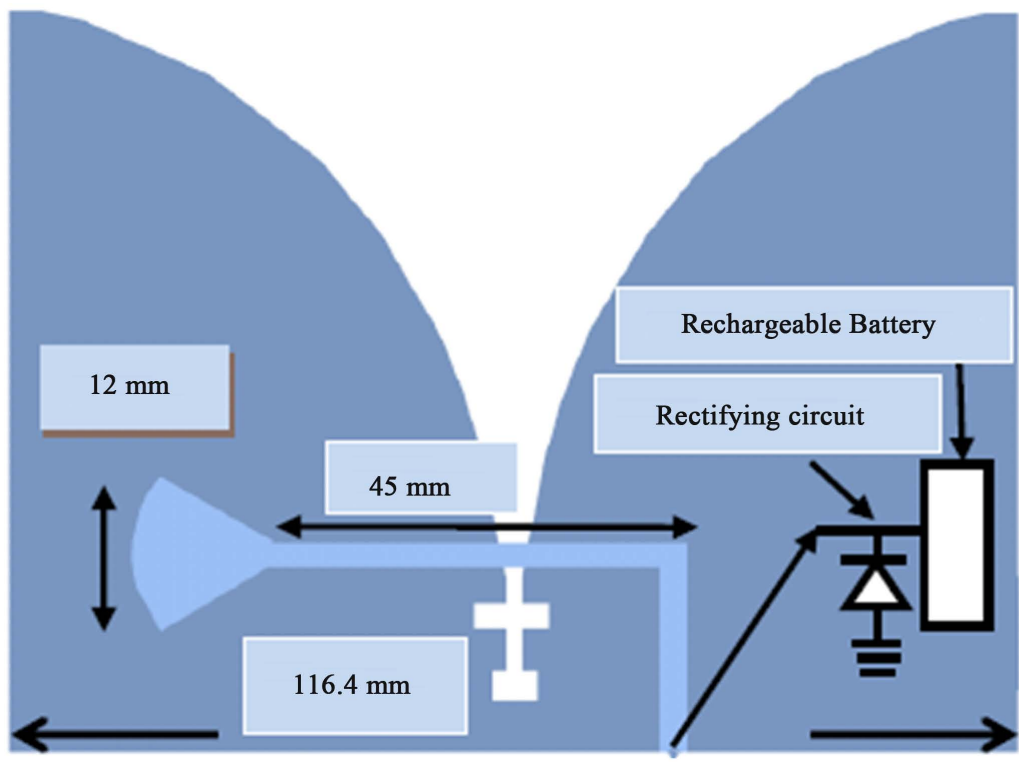

Figure 2. A wideband $2 \mathrm{GHz}$ to $7.8 \mathrm{GHz}$ energy harvesting wearable system. 


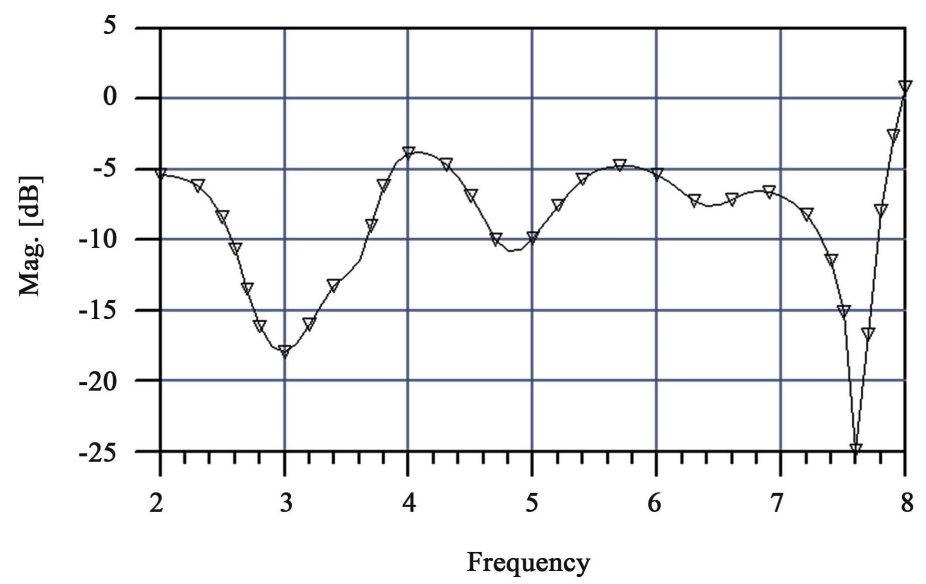

Figure 3. A wideband $2 \mathrm{GHz}$ to $7.8 \mathrm{GHz}$ notch, Computed $\mathrm{S} 11$.

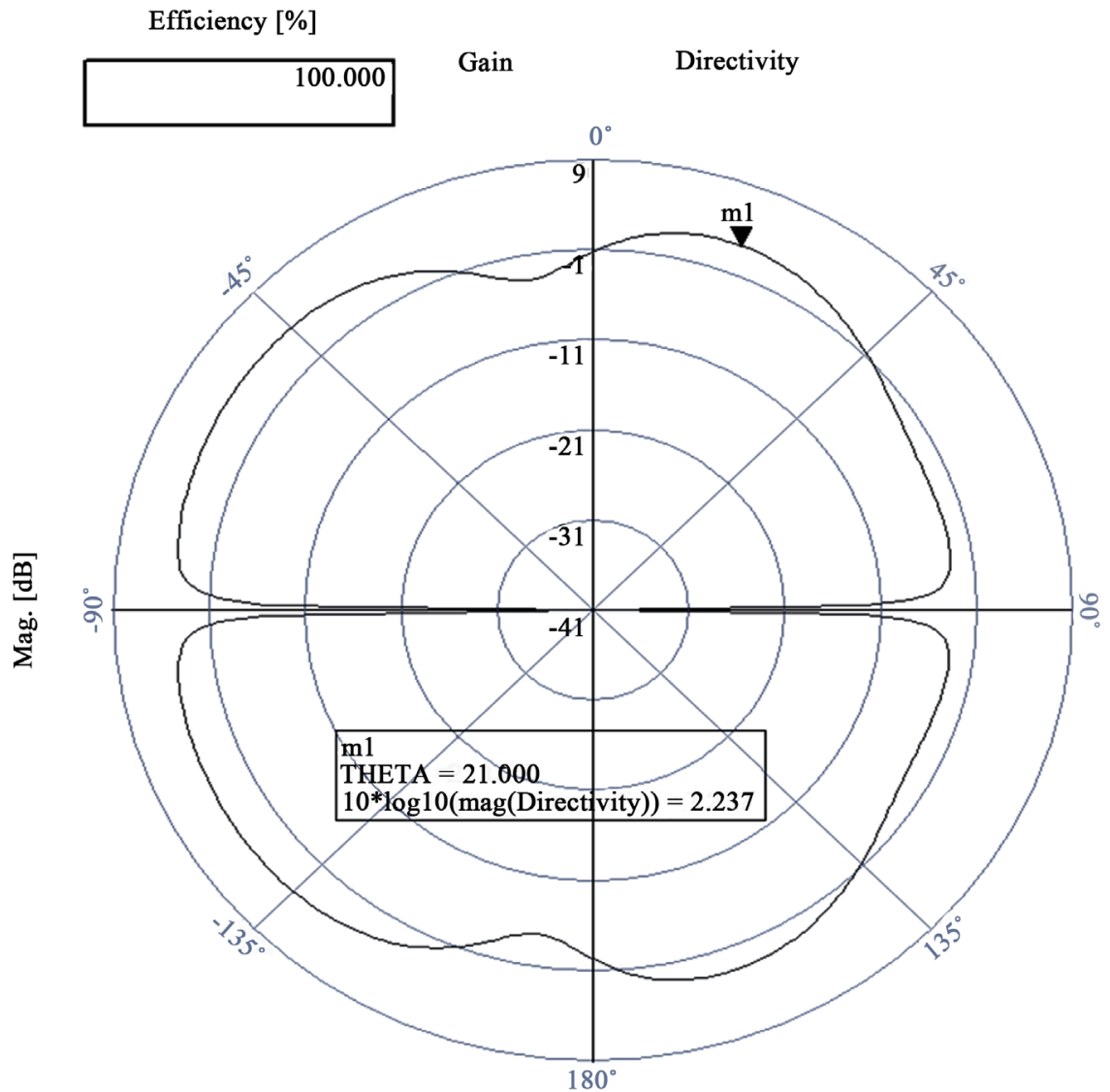

THETA $(-180.000$ to 180.000$)$

Figure 4. Notch antenna radiation pattern, at 3.5 GHz.

\section{New Compact Wideband Active $0.5 \mathrm{GHz}$ to $3 \mathrm{GHz}$ Energy Harvesting System}

Harvested power from RF transmitting links is usually lower than $0.1 \mu \mathrm{W} / \mathrm{cm}^{2}$. Active antennas may improve the energy harvesting system efficiency. A wideband active notch antenna with fractal structure was printed on a $1.2 \mathrm{~mm}$ thick 
substrate with dielectric constant of 2.2.

The active notch antenna dimensions are $74.5 \times 57.1 \mathrm{~mm}$ as presented in Figure 5. The active antenna bandwidth is around $\pm 100 \%$ for $\mathrm{S} 11$ lower than $-5 \mathrm{~dB}$, the antenna center frequency is $1.75 \mathrm{GHz}$. The active antenna S11 is lower than $-5 \mathrm{~dB}$ for frequencies from $0.5 \mathrm{GHz}$ to $3 \mathrm{GHz}$. The antenna azimuth plane beam width is around $84^{\circ}$. An E PHEMT LNA surface mount, Low Noise Amplifier, was connected to a notch antenna via an input matching network. An output matching network connects the amplifier port to the rectifying circuit.A DC bias network supply the required voltages to the amplifiers. Amplifiers electrical parameters was measured by the amplifier manufacturer.The amplifier specification is listed in Table 3. The amplifier complex $S$ parameters are listed in Mini-Circuits datasheets TAV541. The active notch antenna S21 parameter, gain, is presented in Figure 6. The active antenna gain is $22 \pm 2.5 \mathrm{~dB}$ for frequencies ranging from $200 \mathrm{MHz}$ to $900 \mathrm{MHz}$. The active antenna gain is $12.5 \pm 2.5 \mathrm{~dB}$ for frequencies ranging from $1 \mathrm{GHz}$ to $3 \mathrm{GHz}$.

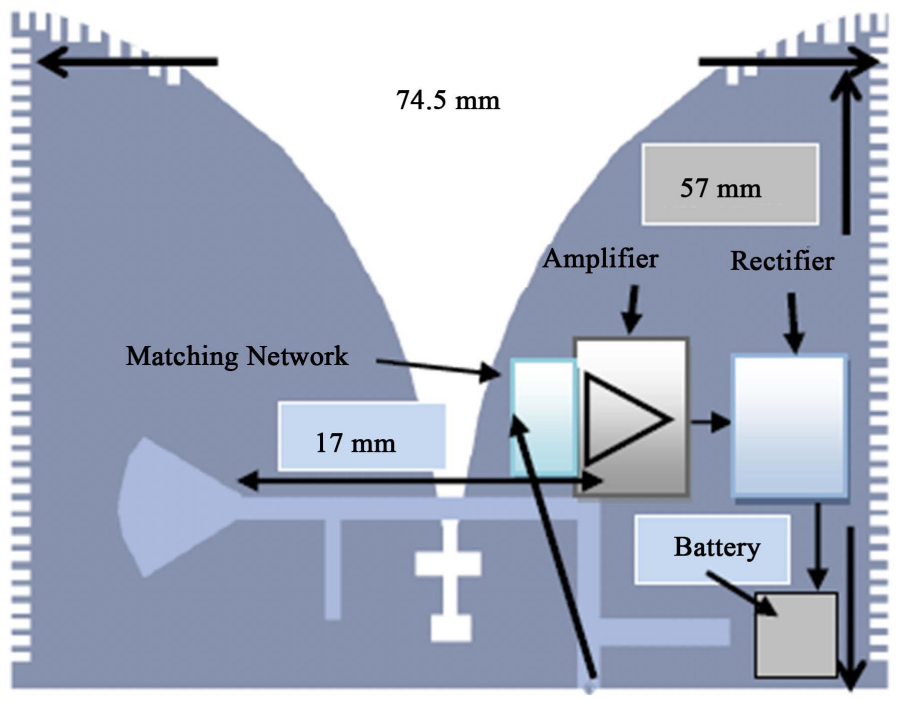

Figure 5. A wideband fractal active wearable notch antenna.

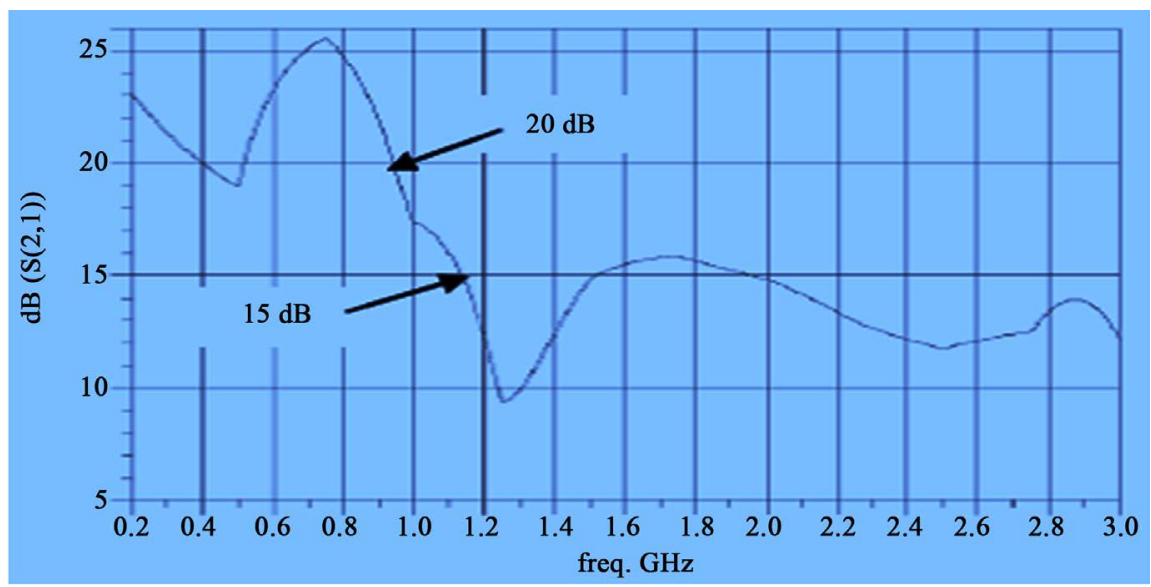

Figure 6. Active notch antenna S21 parameter. 
Table 3. LNA Amplifier specification.

\begin{tabular}{ccc}
\hline Parameter & specification & Remarks \\
\hline Frequency range & $0.4-3 \mathrm{GHz}$ & \\
& $26 \mathrm{~dB} @ 0.4 \mathrm{GHz}$ & $\mathrm{Vds}=3 \mathrm{~V} ;$ \\
Gain & $18 \mathrm{~dB} @ 2 \mathrm{GHz}$ & Ids $=60 \mathrm{~mA}$ \\
& $0.4 \mathrm{~dB} @ 0.4 \mathrm{GHz}$ & $\mathrm{Vds}=3 \mathrm{~V} ;$ \\
N.F & $0.5 \mathrm{~dB} @ 2 \mathrm{GHz}$ & Ids $=60 \mathrm{~mA}$ \\
& $18.9 \mathrm{dBm} @ 0.4 \mathrm{GHz}$ & $\mathrm{Vds}=3 \mathrm{~V} ;$ \\
P1dB & $19.1 \mathrm{dBm} @ 2 \mathrm{GHz}$ & Ids $=60 \mathrm{~mA}$ \\
& $17 \mathrm{~d} \mathrm{Bm}$ & \\
Max. Input power & $0.48 \mathrm{~V}$ & $\mathrm{Vds}=3 \mathrm{~V} ;$ \\
Vgs & $3 \mathrm{~V}$ & \\
Vds & $60 \mathrm{~mA}$ & \\
Ids & &
\end{tabular}

The active notch antenna Noise Figure is presented in Figure 7. The active notch antenna Noise Figure is $0.5 \pm 0.3 \mathrm{~dB}$ for frequencies ranging from 300 $\mathrm{MHz}$ to $3.0 \mathrm{GHz}$. The active notch antenna S22 parameter is lower than $-5 \mathrm{~dB}$ for frequencies from $0.5 \mathrm{GHz}$ to $3 \mathrm{GHz}$. These computed results agree with measured results. All antennas presented in this paper can operate also as passive antennas.

\section{New Wideband Active $0.4 \mathrm{GHz}$ to $3 \mathrm{GHz}$ Energy Harvesting Notch Antenna}

Antenna with fractal structure was printed on a $1.2 \mathrm{~mm}$ thick substrate with dielectric constant of 2.2. The dimensions of the antenna shown in Figure 8 are $52.2 \times 36.8 \mathrm{~mm}$. The active antenna bandwidth is around $\pm 50 \%$ for $\mathrm{S} 11$ lower than $-5 \mathrm{~dB}$, the antenna center frequency is $1.7 \mathrm{GHz}$. The active antenna $\mathrm{S} 11$ is lower than $-5 \mathrm{~dB}$ for frequencies from $0.4 \mathrm{GHz}$ to $3 \mathrm{GHz}$.

An E PHEMT LNA was connected to the antenna. The radiating element is connected to the LNA via an input matching network. An output matching network connects the amplifier port to the rectifying circuit. A DC bias network supplies the required voltages to the energy harvesting system. The amplifier complex S parameters is listed in Mini-Circuits datasheets TAV541. The active notch antenna S21 parameter, gain, is presented in Figure 9. The active antenna gain is $20 \pm 2.5 \mathrm{~dB}$ for frequencies from $400 \mathrm{MHz}$ to $1.3 \mathrm{GHz}$. The active antenna gain is $12.5 \pm 2.5 \mathrm{~dB}$ for frequencies from $1.3 \mathrm{GHz}$ to $3 \mathrm{GHz}$. The antenna beam width is around $84^{\circ}$. The active notch antenna Noise Figure is presented in Figure 10. The active system Noise Figure is $0.5 \pm 0.3 \mathrm{~dB}$ for frequencies from 300 $\mathrm{MHz}$ to $3.0 \mathrm{GHz}$. The active notch antenna $\mathrm{S} 22$ parameter is lower than $-5 \mathrm{~dB}$ for frequencies from $0.5 \mathrm{GHz}$ to $3 \mathrm{GHz}$. 


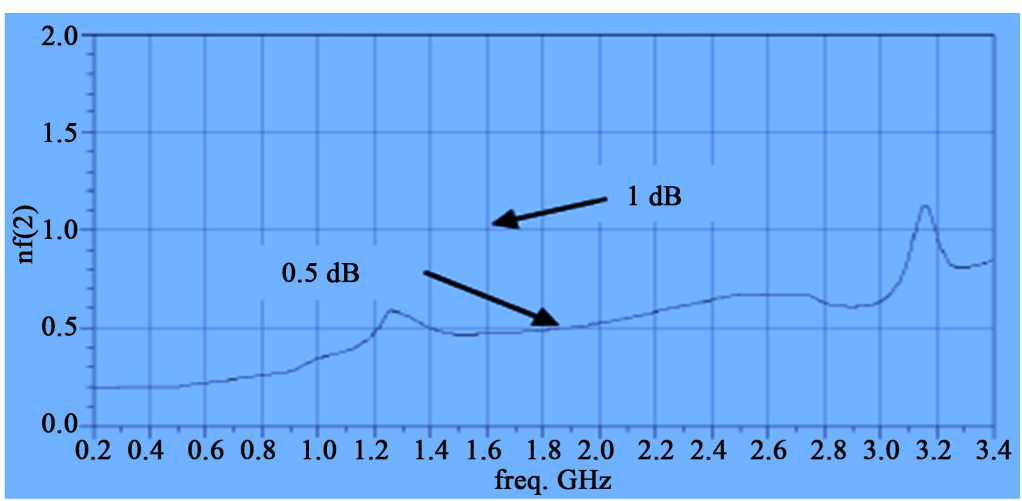

Figure 7. Active notch antenna noise figure.

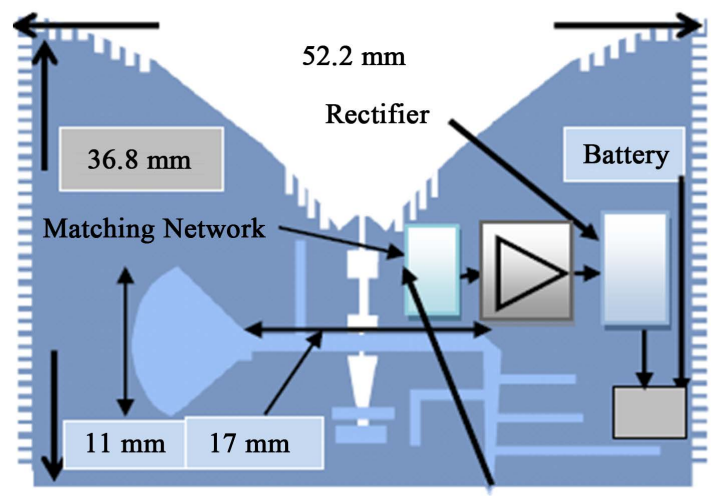

Figure 8. A wideband fractal active notch wearable antenna with fractal structure.

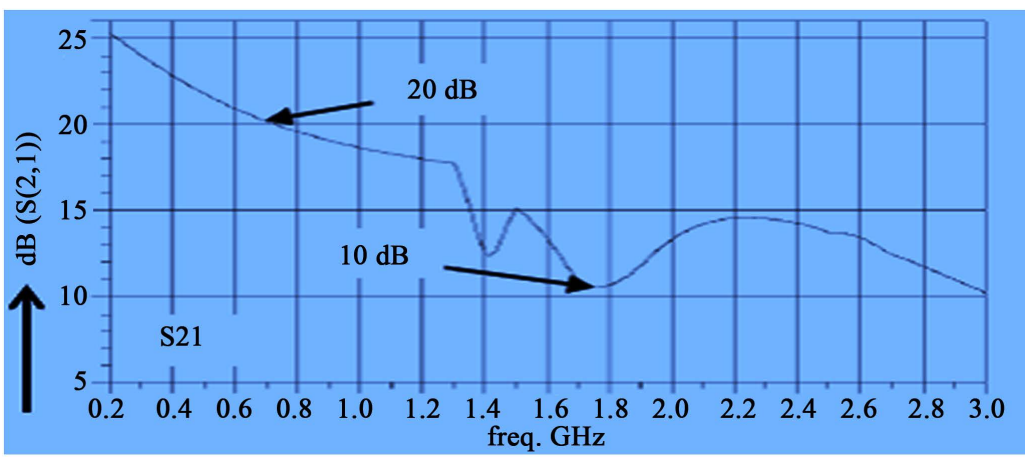

Figure 9. A fractal active notch antenna S21 parameter.

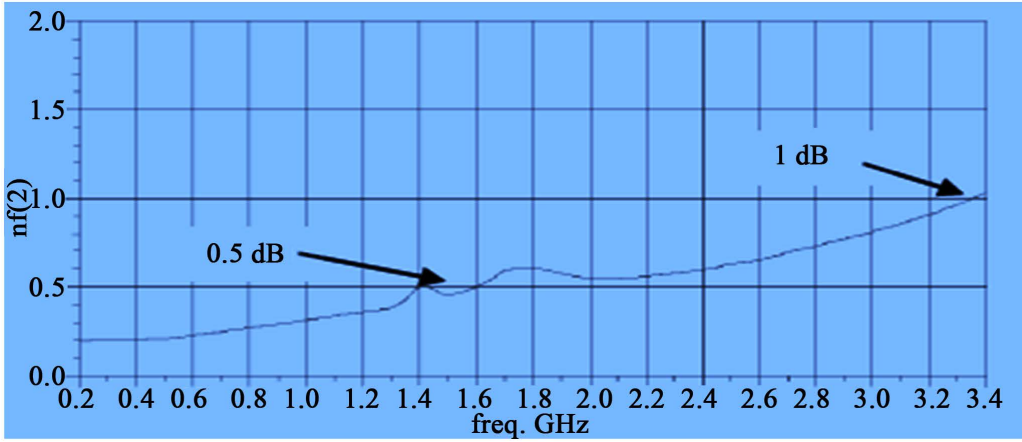

Figure 10. Active fractal notch antenna noise figure. 


\section{New Wideband Active $0.8 \mathrm{GHz}$ to $5.4 \mathrm{GHz}$ Energy Harvestzing Slot Antenna}

A wide band $\mathrm{T}$ shape wearable slot antenna for energy harvesting applications is shown in Figure 11. The antenna electrical parameters were computed by using momentum software [36]. The volume of the $\mathrm{T}$ shape slot antenna is $7 \times 7 \times 0.12$ $\mathrm{cm}$. The slot antenna center frequency is around $3 \mathrm{GHz}$. The computed $\mathrm{S} 11$ parameters are presented in Figure 12. The antenna bandwidth is around $100 \%$ for VSWR better than $3: 1$. The antenna beam-width is around $138^{\circ}$ at $1 \mathrm{GHz}$ as shown in Figure 13. The antenna gain is around $2.5 \mathrm{dBi}$. The antenna was designed also as an active antenna, see Figure 14. The radiating element is connected to the LNA via an input matching network.

An output matching network connects the amplifier output port to a rectifying circuit. A DC bias network supplies the required voltages to the energy harvesting system. The amplifier complex S parameters is listed in Mini-Circuits

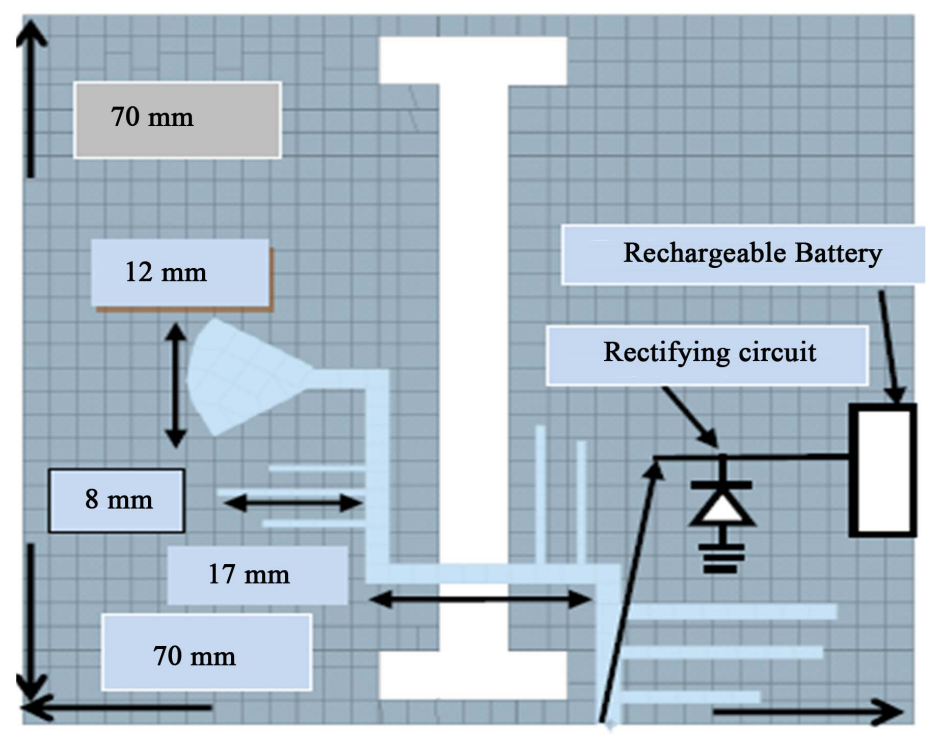

Figure 11. A wideband energy harvesting slot antenna.

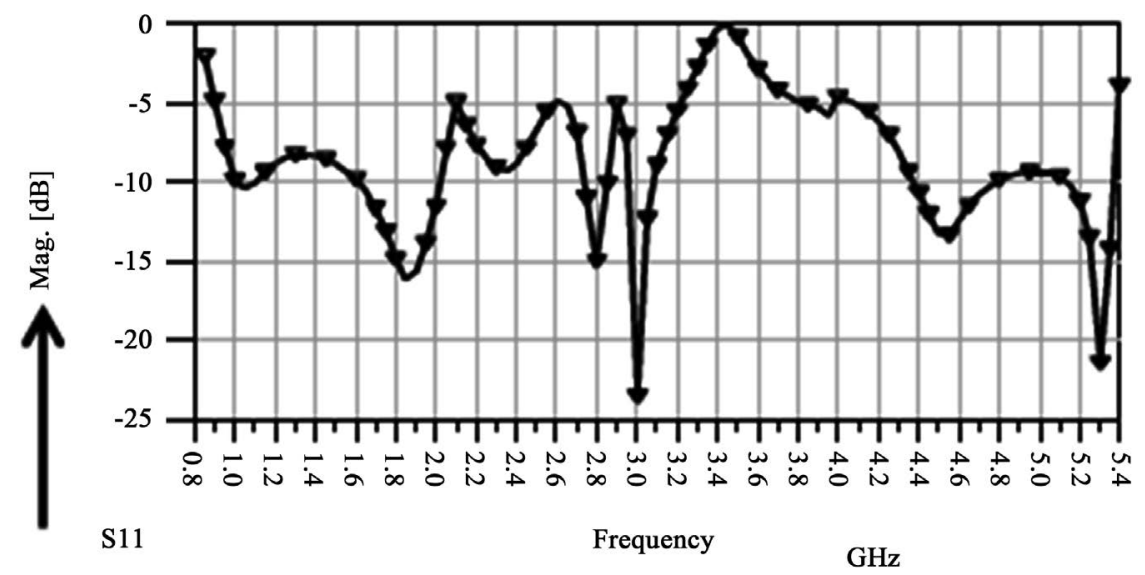

Figure 12. Computed $\mathrm{S} 11$ of a wideband, $0.8 \mathrm{GHz}$ to $5.4 \mathrm{GHz}$, slot. 


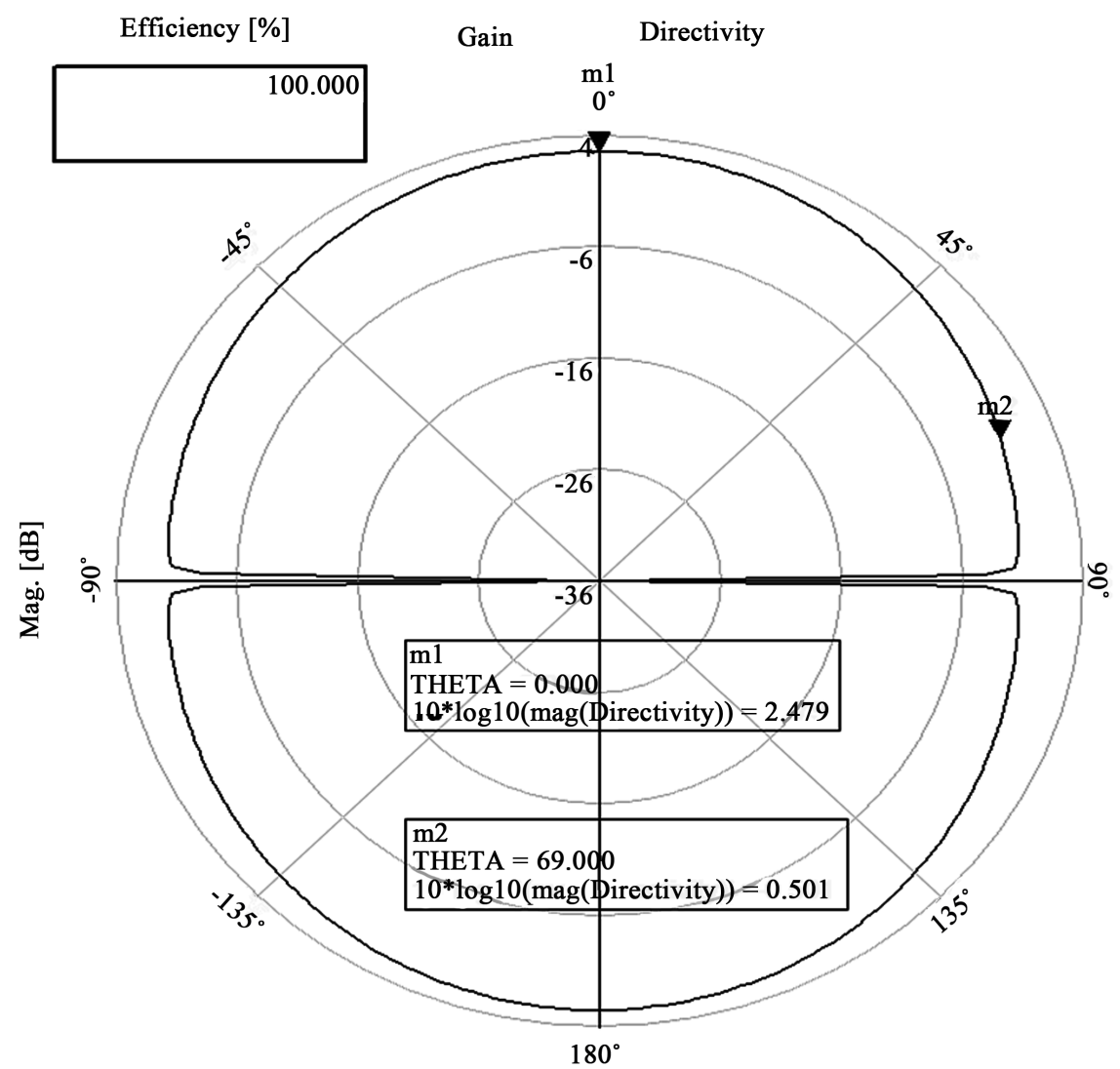

THETA $(-180.000$ to 180.000$)$

Figure 13. Radiation pattern of the energy harvesting slot antenna.

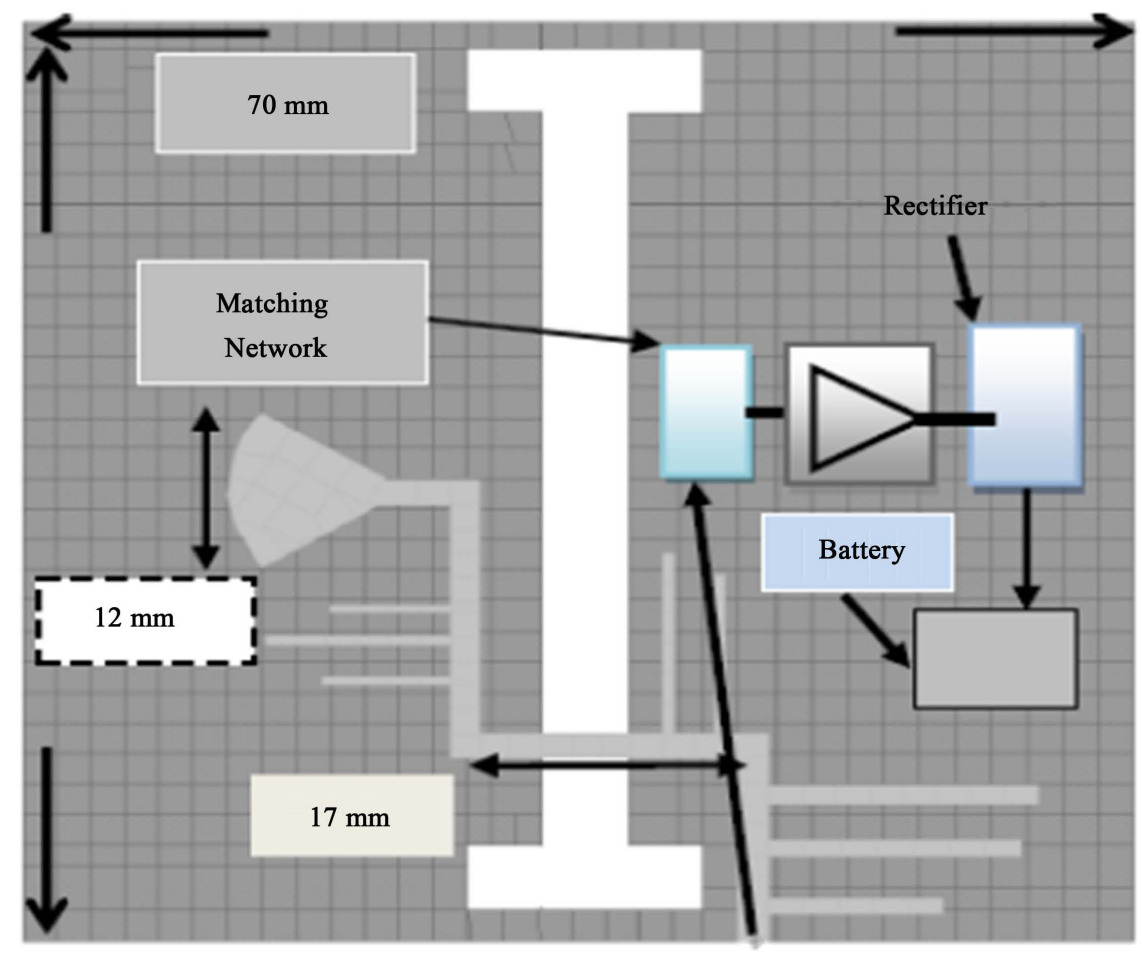

Figure 14. A wideband active energy harvesting slot antenna. 
datasheets TAV541. The active slot antenna S21 parameter, gain, is presented in Figure 15. The active antenna gain is $24 \pm 2.5 \mathrm{~dB}$ for frequencies from $200 \mathrm{MHz}$ to $900 \mathrm{MHz}$. The active antenna gain is $12.5 \pm 2.5 \mathrm{~dB}$ for frequencies from $1 \mathrm{GHz}$ to $3 \mathrm{GHz}$. Gain flatness may be improved to $\pm 2 \mathrm{~dB}$ for frequencies from $0.2 \mathrm{GHz}$ to $6 \mathrm{GHz}$ by using an amplifier with $\pm 2 \mathrm{~dB}$ gain flatness. The active slot antenna Noise Figure is $0.5 \pm 0.3 \mathrm{~dB}$ for frequencies from $200 \mathrm{MHz}$ to $3.0 \mathrm{GHz}$. The S11 parameters of the $\mathrm{T}$ shape slot on human body are presented in Figure 16. The dielectric constant of stomach tissue is 45 see [25] [26]. The antenna was attached, in the stomach area, to a shirt with dielectric constant of $2.21 \mathrm{~mm}$ thick.

\section{Energy Harvesting Wearable Systems for Medical and Sport Applications}

The antennas electrical performance on human body was investigated by using the model shown in Figure 17. Properties of human body tissues are listed in

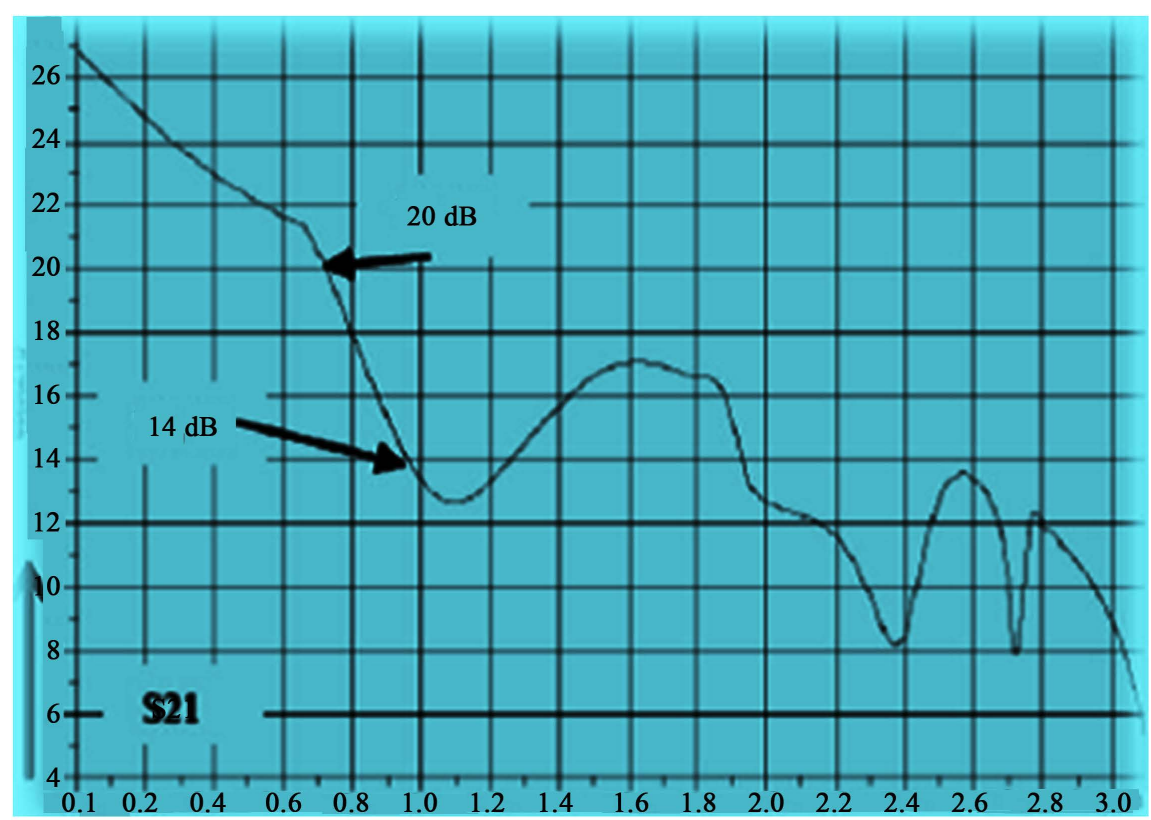

Figure 15. Active energy harvesting slot antenna S21.

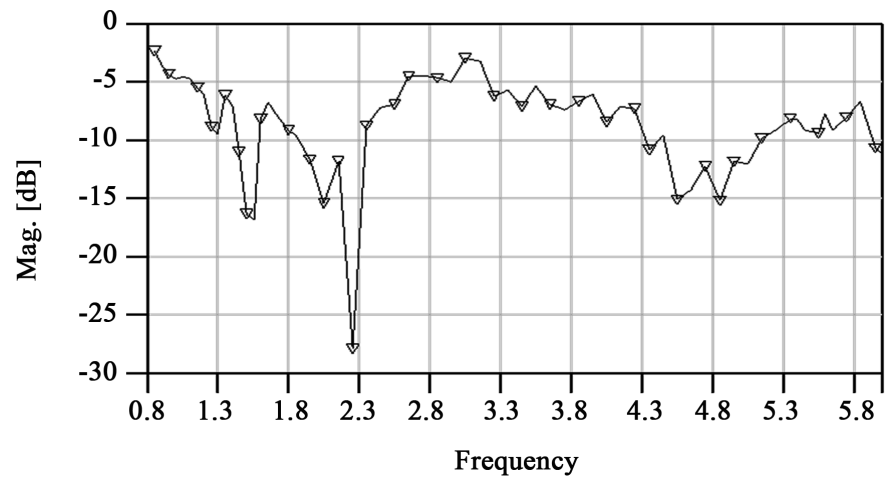

Figure 16. Computed $\mathrm{S} 11$ of a wideband, $0.8 \mathrm{GHz}$ to $5.4 \mathrm{GHz}$, slot Antenna on human body. 


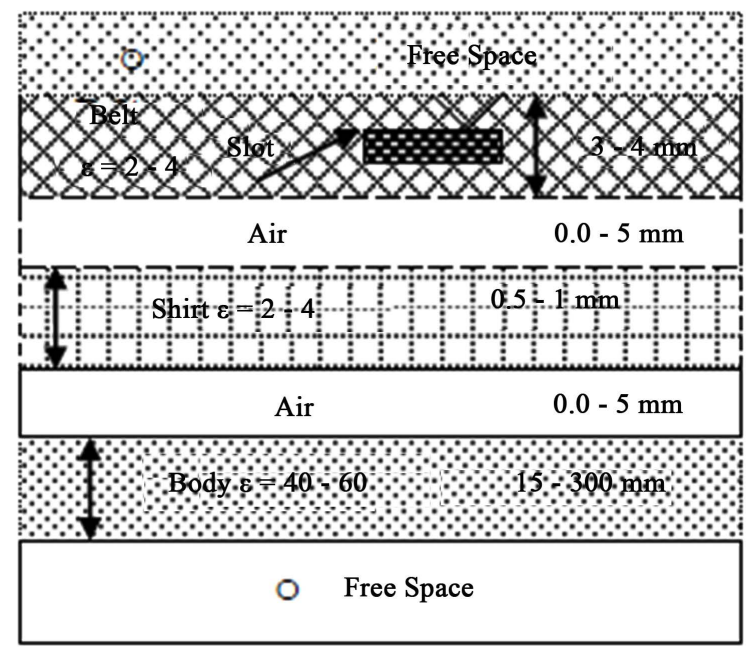

Figure 17. Analyzed structure for wearable slot antennas.

Table 4 [25] [26]. These properties were used in the wearable system development. Several energy harvesting antennas may be assembled in a belt and attached to the human body as illustrated in Figure 18. The bias voltage to the active elements is supplied by a compact recorder battery. The DC cables from each harvesting antenna are connected to a rechargeable battery. Several harvesting passive or active antennas may be inserted to a belt. The converted electromagnetic energy may be used to charge medical or commercial Body Area Networks, BANs.

\section{Energy Harvesting Concept and Efficiency}

As shown in Figure 1 the RF energy harvesting system consists of an antenna, a rectifying circuit and a rechargeable battery. The alternating current (AC), or electromagnetic energy is converted to direct current (DC) by using a rectifier. Half wave rectifier or full wave rectifier may be used to convert electromagnetic energy to DC power. A Half wave rectifier is shown in Figure 19. A half-wave rectifier conducts only during the positive half cycle. Only one half of an AC waveform pass through the load. The rectifier output DC voltage, $V_{O D C}$, is given in Equation (5). The rectifier output voltage may be improved by connecting a capacitor in shunt to the resistor. The improved half wave rectifier is presented in Figure 20. The time constant $\tau$ should be lower than $T$. Where, $\tau=R C \ll T$. The half wave rectifier efficiency is $40.6 \%$ as presented in Equation (7). In this case only $40.6 \%$ of the input electromagnetic power is converted into DC power. The diode resistance $r$ is negligible compared to $\mathrm{R}$. The bridge full wave rectifier is usually used for DC power conversion. It consists of four diodes D1 through D4, as shown in in Figure 21. Terminal A will be positive during the positive input half cycle and terminal B will be negative. Diodes D1 and D2 conducts and D3 and D4 does not conduct. Rectifier output voltage, $V_{O D C}=2 V_{m} / \pi$, may be improved by connecting a capacitor in shunt to the resistor. The improved half wave rectifier is presented in Figure 22. 


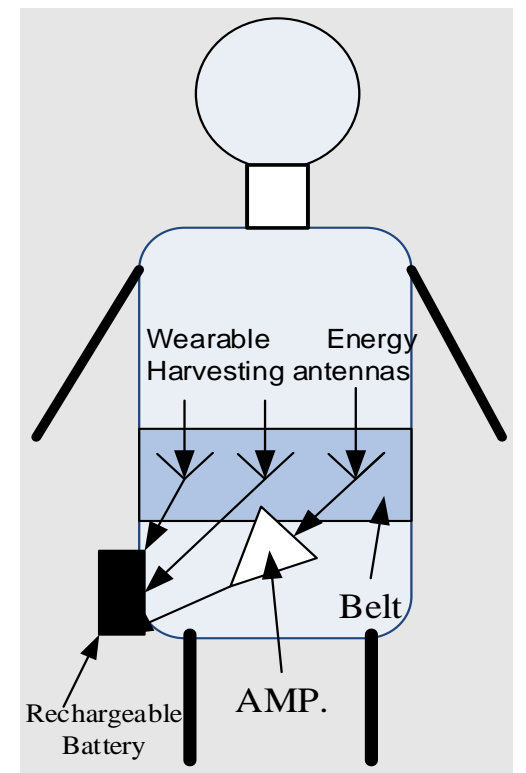

Figure 18. Active wearable energy harvesting system.
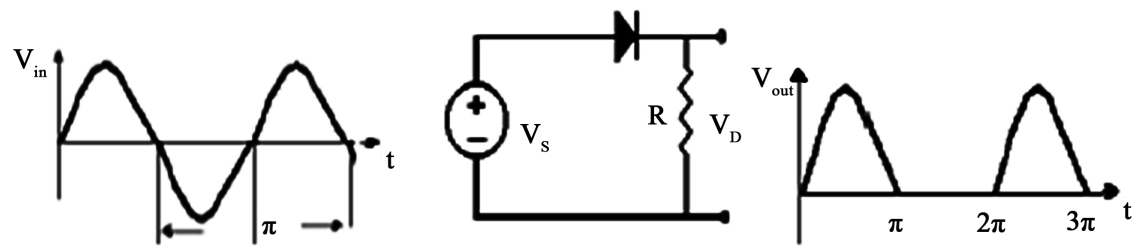

Figure 19. Half wave rectifier.
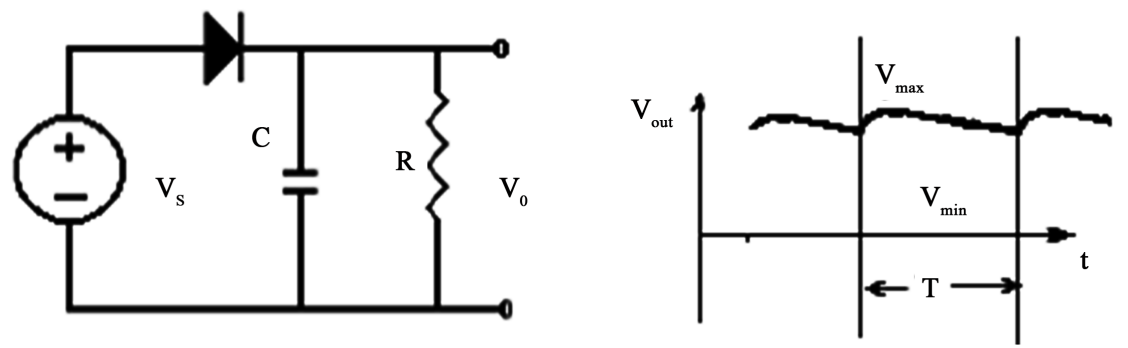

Figure 20. Improved half wave rectifier.

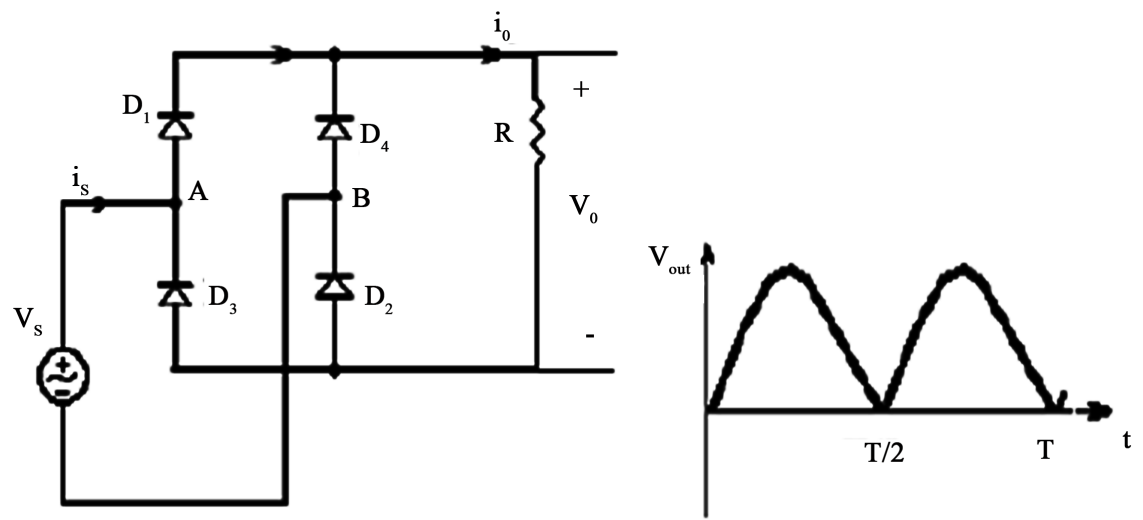

Figure 21. Full wave rectifier. 


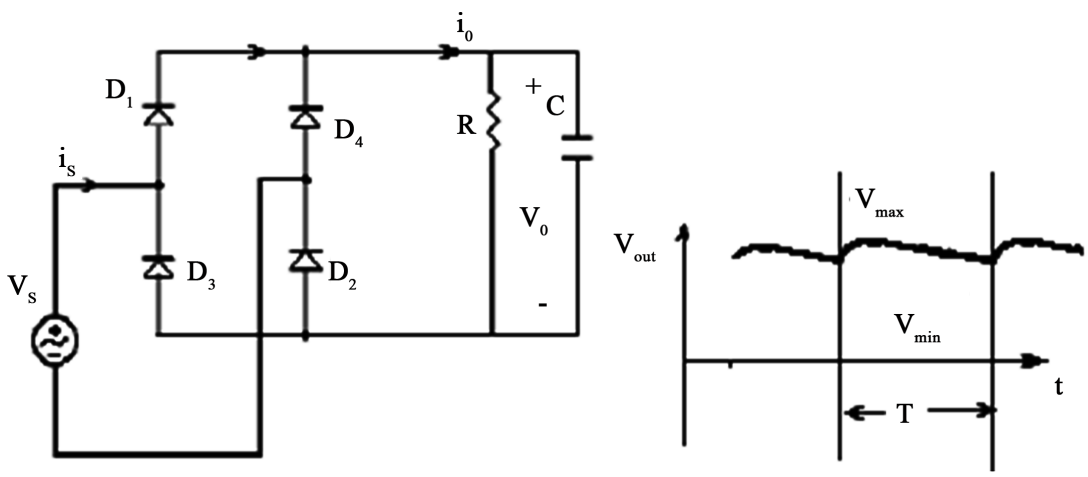

Figure 22. Improved full wave rectifier.

Table 4. Electrical properties of human body tissues

\begin{tabular}{cccc}
\hline Tissue & Property & $600 \mathrm{MHz}$ & $1000 \mathrm{MHz}$ \\
\hline \multirow{2}{*}{ Fat } & $\sigma$ & 0.05 & 0.06 \\
& $\mathcal{E}$ & 5 & 4.52 \\
Stomach & $\sigma$ & 0.73 & 0.97 \\
& $\mathcal{E}$ & 41.41 & 39.06 \\
Colon & $\sigma$ & 1.06 & 1.28 \\
& $\mathcal{E}$ & 61.9 & 59.96 \\
Lung & $\sigma$ & 0.27 & 0.27 \\
& $\mathcal{E}$ & 38.4 & 38.4 \\
Prostate & $\sigma$ & 0.75 & 0.90 \\
& $\mathcal{E}$ & 50.53 & 47.4 \\
Kidney & $\sigma$ & 0.88 & 0.88 \\
& $\mathcal{E}$ & 117.43 & 117.43 \\
\hline
\end{tabular}

$$
\begin{aligned}
& V_{O, D C}=\frac{1}{2 \pi} \int_{0}^{2 \pi} V_{O}^{M A X} \sin (\omega t) \mathrm{d}(\omega t) ; \omega=2 \pi f \\
& V_{O}=V_{S}-V_{D O N} \approx V_{S} ; V_{O}^{M A X}=V_{m} \\
& V_{O D C}=V_{m} / \pi \\
& \text { Vripple }=V r=V m a x-V m i n=\frac{V D C}{f C R} \\
& \eta=\frac{\text { DC output power }}{\text { AC input power }}=\frac{\left(\frac{I_{m}}{\pi}\right)^{2} R}{\left(\frac{I_{m}}{2}\right)^{2}(R+r f)} \sim 0.406
\end{aligned}
$$

The half wave rectifier efficiency is $81.2 \%$ as presented in Equation (8). Only $81.2 \%$ of the input electromagnetic power is converted to DC power.

$$
\eta=\frac{\text { DC output power }}{\text { AC input power }}=\frac{\left(\frac{2 I_{m}}{\pi}\right)^{2} R}{\left(\frac{I_{m}}{2}\right)^{2}(R+r f)} \sim 0.812
$$


The capacitor used in the improved rectifier may be a voltage controlled varactor diode. Varactors are voltage variable capacitors designed to provide electronic tuning of electrical devices. The output voltage ripple, Equation (6), of the improved rectifier may be tuned as function of the frequency of the received signal or of the load resistance R. A Schottky diode may be employed in the rectifier circuit. Schottky diode is a semiconductor PN junction. Schottky diodes has a low forward voltage drop and a very fast switching time. When current flows through the diode there is a small voltage drop across the diode terminals. Conventional diodes have a voltage drop between 0.6 to 1.7 volts. The voltage drop of a Schottky diode is significantly lower and is between 0.2 to 0.4 volts. This lower voltage drop results in higher system efficiency and better switching speed. Comparison of Schottky diode and standard PN diodes is listed in Table 5. Typical I-V curves of commercial schottky diodes are shown in Figure 23. Figure 24 presents a wearable harvesting system and a wearable battery charger attached to the patient shirt.

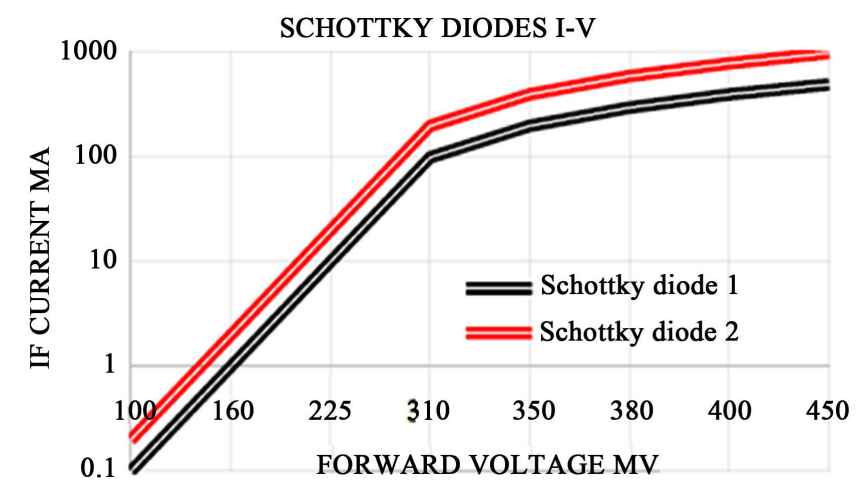

Figure 23. Typical I-V curves of schottky diodes.

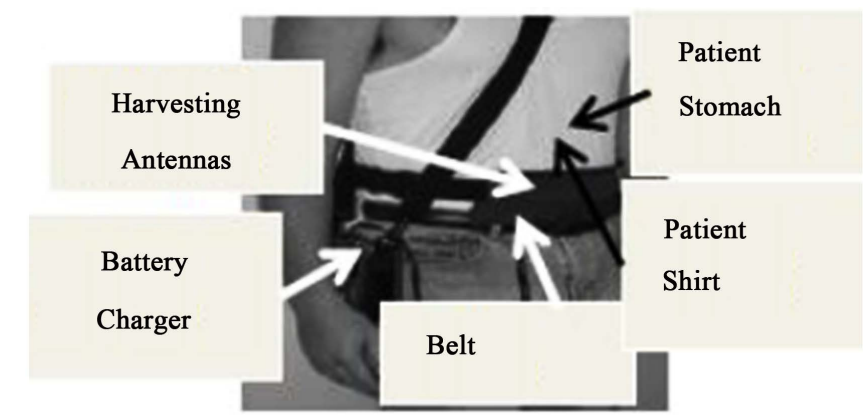

Figure 24. Medical wearable harvesting system.

Table 5. Comparison of Schottky diode and standard PN diodes.

\begin{tabular}{ccc}
\hline PARAMETER & SCHOTTKY DIODE & PN DIODE \\
\hline Forward current mechanism & Majority carrier transport & Minority carrier transport \\
Reverse current & Less temperature dependence & Strong temperature \\
Turn on voltage & Small-around $0.2 \mathrm{~V}$ & Comparatively large around 0.7 V \\
Switching speed & Fast & Limited \\
\hline
\end{tabular}




\section{Conclusion}

This paper presents new compact Ultra-Wideband wearable active energy harvesting systems for wearable sensors in frequencies from $0.4 \mathrm{GHz}$ to $8 \mathrm{GHz}$. The active wearable notch and slot antennas were analyzed by using 3D full-wave software. Harvested power from RF transmitting links is usually lower than 0.1 $\mu \mathrm{W} / \mathrm{cm}^{2}$. Active antennas may improve the energy harvesting system efficiency. However, all antennas presented in this paper can operate also as passive antennas. The active notch and slot antenna bandwidth is from $50 \%$ to $100 \%$ with VSWR better than $3: 1$. The slot antenna gain is around $3 \mathrm{dBi}$ with efficiency higher than $90 \%$. The antenna electrical parameters were computed in vicinity of the human body. The active slot antenna gain is $24 \pm 2.5 \mathrm{~dB}$ for frequencies from $200 \mathrm{MHz}$ to $900 \mathrm{MHz}$. The active slot antenna gain is $12 \pm 2 \mathrm{~dB}$ for frequencies from $1 \mathrm{GHz}$ to $3.3 \mathrm{GHz}$. The gain flatness of the energy harvesting system may be improved by using an amplifier with better gain flatness. We can use an amplifier with $\pm 2 \mathrm{~dB}$ gain flatness for frequencies from $0.2 \mathrm{GHz}$ to $6 \mathrm{GHz}$. Active wearable antennas may be used in energy harvesting systems. A low noise amplifier is connected to the energy harvesting antenna. An output matching network connects the amplifier output port to a rectifying circuit. A rechargeable battery is connected to the output of the rectifying circuit. The wearable harvesting system components are assembled on the same PCB. The proposed energy harvesting system may be used in wearable wireless communication and medical sensors and systems.

\section{References}

[1] Lu, X., Wang, P. and Niyato, D. (2015) Wireless Networks With RF Energy Harvesting: A Contemporary Survey. IEEE Communications Surveys \& Tutorials Volume, 17, 757-789. https://doi.org/10.1109/COMST.2014.2368999

[2] Visser, H.J. and Vullers, R.J.M. (2013) RF Energy Harvesting and Transport for Wireless Sensor Network Applications: Principles and Requirements. IEEE, 101, 1410-1423. https://doi.org/10.1109/JPROC.2013.2250891

[3] Paradiso, J.A. and Starner, T. (2005) Energy Scavenging for Mobile and Wireless Electronics. IEEE Pervasive Computing, 4, 18-27.

https://doi.org/10.1109/MPRV.2005.9

[4] Valenta, C.R. and Durgin, G.D. (2014) Harvesting Wireless Power: Survey of Energy-Harvester Conversion Efficiency in Far-Field, Wireless Power Transfer Systems. IEEE Microwave Magazine, 15, 108-120. https://doi.org/10.1109/MMM.2014.2309499

[5] Nintanavongsa, P., Muncuk, U., Lewis, D.R. and Chowdhury, K.R. (2012) Design Optimization and Implementation for RF Energy Harvesting Circuits. IEEE Journal on Emerging and Selected Topics in Circuits and Systems, 2, 24-33. https://doi.org/10.1109/JETCAS.2012.2187106

[6] Devi, K.K.A., Sadasivam, S., Din, N.M. and Chakrabarthy, C.K. (2011) Design of a $377 \Omega$ Patch Antenna for Ambient RF Energy Harvesting at Downlink Frequency of GSM 900. Proceedings of the 17 th Asia Pacific Conference on Communications (APCC '11), Sabah, October 2011, 492-495. 
https://doi.org/10.1109/APCC.2011.6152859

[7] Rahim, R.A., Malek, F., Anwar, S.F.W., Hassan, S.L.S., Junita, M.N. and Hassan, H.F. (2013) A Harmonic Suppression Circularly Polarized Patch Antenna for an RF Ambient Energy Harvesting System. Proceedings of the IEEE Conference on Clean Energy and Technology (CEAT'13), IEEE, Lankgkawi, November 2013, 33-37. https://doi.org/10.1109/CEAT.2013.6775595

[8] Krakauskas, M., Sabaawi, A.M.A. and Tsimenidis, C.C. (2014) Suspended Patch Microstrip Antenna with Cut Rectangular Slots for RF Energy Harvesting. Proceedings of the 10 th Loughborough Antennas and Propagation Conference (LAPC '14), Loughborough, November 2014, 304-307. https://doi.org/10.1109/LAPC.2014.6996382

[9] Sabban, A. (2015) Low Visibility Antennas for Communication Systems. Taylor \& Francis Group, Abingdon.

[10] Sabban, A. (2016) Wideband RF Technologies and Antenna in Microwave Frequencies. Wiley Sons, New York. https://doi.org/10.1002/9781119048640

[11] James, J.R., Hall, P.S and Wood, C. (1981) Microstrip Antenna Theory and Design. The Institution of Engineering and Technology, London. https://doi.org/10.1049/PBEW012E

[12] Sabban, A. and Gupta, K.C. (1991) Characterization of Radiation Loss from Microstrip Discontinuities Using a Multiport Network Modeling Approach. I.E.E.E Trans. on M.T.T, 39, 705-712.

[13] Sabban, A. (1983) A New Wideband Stacked Microstrip Antenna. I.E.E.E Antenna and Propagation Symposium, Houston.

[14] Balanis, C.A. (1996) Antenna Theory: Analysis and Design. 2nd Edition, Wiley, Hoboken.

[15] Sabban, A. (1986) Microstrip Antenna Arrays. US Patent No. 1986/4,623,893.

[16] Sabban, A. (1981) Wideband Microstrip Antenna Arrays. I.E.E.E Antenna and Propagation Symposium MELCOM, Tel-Aviv.

[17] Fujimoto, K. and James, J.R. Editors (1994) Mobile Antenna Systems Handbook. Artech House, Boston.

[18] Sabban, A. (2016) New Wideband Notch Antennas for Communication Systems. Wireless Engineering and Technology Journal, 7, 75-82. https://doi.org/10.4236/wet.2016.72008

[19] Sabban, A. (2012) Dual Polarized Dipole Wearable Antenna. US Patent No. 8203497.

[20] Sabban, A. (2012) Wideband Tunable Printed Antennas for Medical Applications. I.E.E.E Antenna and Propagation Symposium, Chicago.

[21] Sabban, A. (2013) New Wideband Printed Antennas For Medical Applications. IEEE Transactions on Antennas and Propagation, 61, 84-91.

[22] Sabban, A. (2013) Comprehensive Study of Printed Antennas on Human Body for Medical Applications. International Journal of Advance in Medical Science (AMS), 1, 1-10.

[23] Kastner, R., Heyman, E. and Sabban, A. (1988) Spectral Domain Iterative Analysis of Single and Double-Layered Microstrip Antennas Using the Conjugate Gradient Algorithm. IEEE Transactions on Antennas and Propagation, 36, 1204-1212.

[24] Sabban, A. (2011) Microstrip Antenna Arrays. Microstrip Antennas, Nasimuddin Nasimuddin, InTech, 361-384.

http://www.intechopen.com/articles/show/title/microstrip-antenna-arrays 
[25] Chirwa, L.C., Hammond, P.A., Roy, S. and Cumming, D.R.S. (2003) Electromagnetic Radiation from Ingested Sources in the Human Intestine between $150 \mathrm{MHz}$ and 1.2 GHz. IEEE Transactions on Biomedical Engineering, 50, 484-492.

[26] Werber, D., Schwentner, A. and Biebl, E.M. (2006) Investigation of RF Transmission Properties of Human Tissues. Advances in Radio Science, 4, 357-360. https://doi.org/10.5194/ars-4-357-2006

[27] Gupta, B., Sankaralingam, S. and Dhar, S. (2010) Development of Wearable and Implantable Antennas in the Last Decade. Microwave Symposium (MMS), Mediterranean, 251-267. https://doi.org/10.1109/MMW.2010.5605178

[28] Thalmann, T., Popovic, Z., Notaros, B.M. and Mosig, J.R. (2009) Investigation and Design of a Multi-Band Wearable Antenna. 3rd European Conference on Antennas and Propagation, 462-465.

[29] Salonen, P., Rahmat-Samii, Y. and Kivikoski, M. (2004) Wearable Antennas in the Vicinity of Human Body. IEEE Antennas and Propagation Society International Symposium, 1, 467-470. https://doi.org/10.1109/APS.2004.1329675

[30] Kellomaki, T., Heikkinen, J. and Kivikoski, M. (2006) Wearable Antennas for FM Reception. 1st European Conference on Antennas and Propagation, 1-6.

[31] Sabban, A. (2015) New Wideband Meta Materials Printed Antennas for Medical Applications. International Journal of Advance in Medical Science (AMS), 3, 1-10. https://doi.org/10.12783/ams.2015.0301.02

[32] Sabban, A. (2009) Wideband Printed Antennas for Medical Applications. APMC 2009 Conference, Singapore.

[33] Alomainy, A., Sani, A., et al. (2009) Transient Characteristics of Wearable Antennas and Radio Propagation Channels for Ultrawideband Body-Centric Wireless Communication. IEEE Transactions on Antennas and Propagation, 57, 875-884.

[34] Klemm, M. and Troester, G. (2006) Textile UWB Antenna for Wireless Body Area Networks. IEEE Transactions on Antennas and Propagation, 54, 3192-3197.

[35] Izdebski, P.M., Rajagoplan, H. and Rahmat-Sami, Y. (2009) Conformal Ingestible Capsule Antenna: A Novel Chandelier Meandered Design. IEEE Transactions on Antennas and Propagation, 57, 900-909.

[36] ADS Momentum Software, Keysightt. http://www.keysight.com/en/pc-1297113/advanced-design-system-ads?cc=IL\&lc=e $\underline{\mathrm{ng}}$ 